\section{U.S. GEOLOGICAL SURVEY FEDERAL-STATE COOPERA- TIVE WATER-RESOURCES PROGRAM IN NEBRASKA}

Federal, State, and local agencies share keen interests in appraising the Nation's water resources and in seeking solutions to waterrelated problems. The U.S. Geological Survey (USGS) Federal-State Cooperative Water-Resources Program was initiated in 1895 to address the diversity in missions and areas of responsibility of various agencies through joint planning and funding of hydrologic data collection, investigations, and research. During the 100-year history of the cooperative program, the USGS has performed many data-collection and investigation activities in cooperation with a variety of State and local agencies to help meet their goals and to carry out the principal mission of the Water Resources Division of the USGS--to further the understanding of water resources throughout the Nation. The cooperative program represents almost 50 percent of USGS water-related activities in Nebraska and is a vital component in addressing water issues of local, State, and National interest.

\section{WATER-RESOURCES INFOR- MATION ACTIVITIES}

The USGS provides high-quality, impartial information on water resources to its customers in Nebraska and throughout the Nation by performing four principal functions.

- Collecting essential data for the continued evaluation of the quantity, quality, and use of the Nation's water resources.

- Conducting analytical and interpretive appraisals to describe the occurrence, availability, and physical, chemical, and biological characteristics of surface and ground water.

- Conducting investigations and research in hydraulics, hydrology, and related scientific and engineering fields.

- Disseminating water data and the results of investigations and research.

About half of the funds in Nebraska's Federal-State Cooperative Program support the collection of hydrologic data; the remaining funds support hydrologic investigations and research. The information that results from data collection, investigations, and research helps customers solve problems related to water resources in Nebraska. Some examples of the types and applications of information provided by the USGS and current cooperative partners in Nebraska are described below.

\section{Surface-Water Quantity Information}

Cooperators--State and local agencies in Nebraska cooperating with the USGS include the City of Lincoln, KansasNebraska Blue River Compact Administration, Lancaster County, Nebraska Department of Roads, Nebraska Department of Water Resources, Nebraska Game and Parks Commission, and the following Natural Resources Districts (NRDs)--Central Platte, Lower Platte South, and Lower Platte North. Federal agencies working with the USGS in obtaining streamflow information, which supplements the Federal-State Cooperative Program, are the U.S. Army Corps of Engineers, the Bureau of Reclamation, and the Federal Highway Administration.

Problem--Surface-water information such as stage and discharge is needed for purposes of surveillance, planning, design, hazard warning, operation, and management in such water-related fields as water supply, hydroelectric power, flood control, irrigation, and water-resources development. Information on streamflow extremes (floods and droughts) is needed for managing stream systems to reduce adverse effects and to manage risk. In addition, new high way construction and structure replacements require the crossing of many waterways. Accurate information on the water level and flow at these crossings is vital to safe and cost-effective bridge design.

USGS Role--The U.S. Geological Survey in Nebraska systematically and routinely gathers data from 122 automated surface-watergaging stations (fig. 1). The Federal-State Cooperative Program funds 73 of those stations and 80 partial-record stations (as of October 1994). Real-time data are available from 40 of these stations through satellite transmission and from 11 stations through telephone lines for immediate retrieval of current stream stages. Hydrologic data collected in Nebraska as part of the waterresources data network are published annually in a comprehensive report and are available on CD-ROM. Streamflow information is also used by the USGS to compute floodfrequency statistics. Flood-frequency reports are produced approximately every 10 years to update flood-frequency statistics for gaging stations and to update regional equations used to estimate flow at ungaged sites.

Cooperator's Use of Information--Cooperators and many other public and private entities use USGS streamflow data for many purposes, such as determination of watersupply availability and in making management decisions. Surface-water data are needed for efficient operation of water-sup-

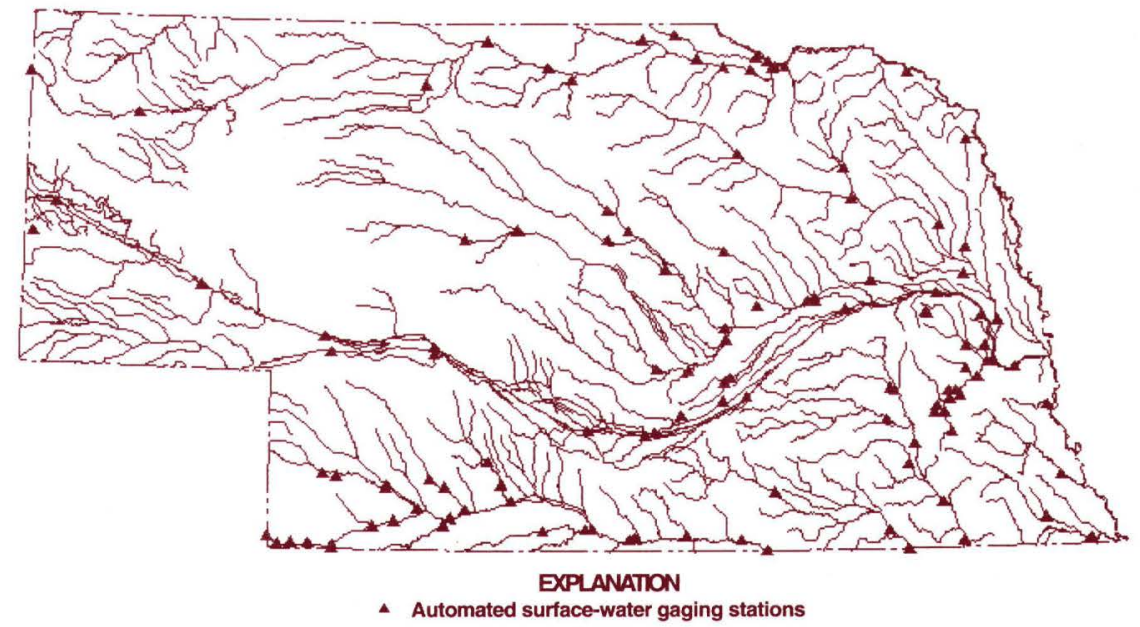

Figure 1. -- Location of continuous-record surface-water gaging stations in Nebraska, 1994. 
ply reservoirs and design of new drinkingwater and wastewater facilities. Real-time data are needed for flood control, flood warning, and flood-plain management. USGS surface-water data were of vital importance to minimize loss of life and property damage as recent as the 1993 floods in the Midwest. Other uses of the data include hydroelectric-power management, interstate and within-State waterrights administration and resolution of conflicts, water-quality loading and waste loading of streams, time of travel for hazardous spills, and efficient design of highway bridges, culverts, and other facilities. Floodfrequency information is used by Nebraska Department of Roads and other public and private entities for efficient design of bridges, culverts, and other structures. This information makes cost-effective floodplain management regulations, plans, and structural controls possible.

\section{Ground-Water Quantity Information}

Cooperators--State and local agencies in Nebraska cooperating with the USGS include City of Lincoln; University of Nebraska-Lincoln, Conservation and Survey Division; and the following Natural Resources Districts: Central Platte; Lower Elkhorn; Lower Republican; Lower Platte North; Lower Platte South; Middle Republican; Nemaha; North Platte; South Platte; Twin Platte; Upper Big Blue; Upper Elkhorn; Upper Loup; Upper NiobraraWhite; and Upper Republican. Federal agencies working with the USGS to supplement the Federal-State Cooperative Program in ground water are the Bureau of Reclamation and the U.S. Department of Energy.

Problem--Long-term ground-water-level data are necessary to help identify and document changes in water levels, so that potential problems can be defined early enough to allow proper planning and management. For example, about 30 percent of all ground water used for irrigation in the United States is pumped from the High Plains aquifer, which underlies one of the major agricultural regions in the United States, including most of Nebraska. Because of the importance of this source of water, it is vital that accurate information on the conditions and changes in the aquifer be maintained.

USGS Role--The USGS compiles, reviews, and maintains, in a national data base, ground-water-level data collected from more than 3,500 wells annually in Nebraska by numerous Federal, State, and local agen- cies. These data allow for a description of water-level conditions in the High Plains aquifer, as well as in other aquifers throughout the State. The USGS publishes an annual report describing annual and historical water-level changes for the High Plains aquifer from South Dakota to Texas. Ground-water-level data are needed for calibrating ground-water-flow models, developed by the USGS to assist water managers in effectively managing ground-water resources throughout the State. Groundwater levels collected in Nebraska as part of the water-resources data network are published annually in a comprehensive report and are available on CD-ROM.

\section{Cooperator's Use of Information--The}

ground-water-level information helps State and local agencies to make sound management decisions concerning the use of water, to measure the effects of development, to assist in the projection of future water supplies, and to conduct hydrologic research. The State publishes an annual report summarizing water-level changes in Nebraska.

\section{Surface- and Ground-Water Quality Information}

Cooperators--State and local agencies in Nebraska cooperating with the USGS include City of Lincoln; Nebraska Natural Resources Commission; Nebraska Department of Environmental Quality; Nebraska Department of Health; and the following NRDs: Big Blue; Central Platte; Little Blue; Lower Republican; Middle Republican; Nemaha; Lower Platte North; Lower Platte South; North Platte; Papio-Missouri River; and Upper Republican. The U.S. Department of Interior, the Bureau of Reclamation, and the U.S. Environmental Protection Agency work with the USGS to supplement the Federal-State Cooperative Program in water quality.

Problem--Water-resources planning and water-quality assessment require both a local and nationwide base of standardized information on the chemical and physical quality of rivers, streams, lakes, and reservoirs, as well as major ground-water systems. Because Nebraska has some of the most intensively cultivated and irrigated land in the Nation, Nebraska's waters have become contaminated in some areas.

USGS Role--The USGS provides waterquality monitoring and maintains a national data base of water-quality information. The USGS has completed or is currently involved in ground-water-quality reconnaissance studies with several NRDs to deter- mine the general chemical character of water, to assess the principal factors that affect water quality, and to assess future changes in water quality. In additional projects, the USGS is monitoring streamwater quality because of increasing demand for surface water for domestic and recreational uses and is examining the interaction between ground and surface water. The USGS has completed or is currently involved in investigations to establish ground-water-monitoring networks within Special Protection Areas (SPAs) (designated areas particularly susceptible to nitrate contamination of the ground water), to determine the seasonal variability of nitrate concentrations in ground water, and to examine movement rates of nitrogen from the land surface through the unsaturated zone to the aquifer.

\section{Cooperator's Use of Information--NRDs} use the information as part of their groundwater-management plans, which require identification of locations and concentrations of ground-water contamination and monitoring of levels of selected contaminants. As part of the SPAs, NRDs use the information to determine water-quality changes that result from alternative landmanagement practices. State agencies and NRDs use the data to detect and assess long-term changes in water quality. The City of Lincoln uses the water-quality information to assist in managing water supply from its well field near Ashland.

—Linda S. Weiss

Further information on the Federal-State Cooperative Water-Resources Program in Nebraska or U.S. Geological Survey programs in general can be obtained from:

District Chief

U.S. Geological Survey

Water Resources Division

Room 406 Federal Building

100 Centennial Mall, North

Lincoln, Nebraska 68508

(402) 437-5082

FAX (402) 437-5139

e-mail:info@ne20dnelnc.cr.usgs.gov 